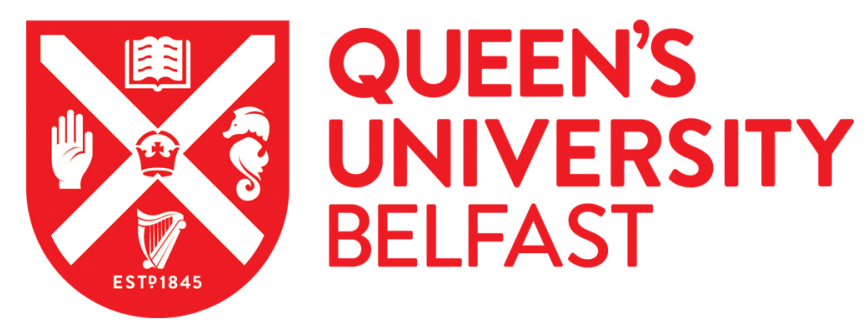

\title{
Living Independently: Exploring the Experiences of Visually Impaired People Living in Age-Related and Lifetime Housing Through Qualitative Synthesis
}

Rooney, C., Hadjri, K., Faith, V., Rooney, M., McAllister, K., \& Craig, C. (2017). Living Independently: Exploring the Experiences of Visually Impaired People Living in Age-Related and Lifetime Housing Through Qualitative Synthesis. Health Environments Research \& Design Journal. https://doi.org/10.1177/1937586717696699

Published in:

Health Environments Research \& Design Journal

Document Version:

Peer reviewed version

Queen's University Belfast - Research Portal:

Link to publication record in Queen's University Belfast Research Portal

Publisher rights

(C) 2017 The Authors.

This work is made available online in accordance with the publisher's policies. Please refer to any applicable terms of use of the publisher.

\section{General rights}

Copyright for the publications made accessible via the Queen's University Belfast Research Portal is retained by the author(s) and / or other copyright owners and it is a condition of accessing these publications that users recognise and abide by the legal requirements associated with these rights.

Take down policy

The Research Portal is Queen's institutional repository that provides access to Queen's research output. Every effort has been made to ensure that content in the Research Portal does not infringe any person's rights, or applicable UK laws. If you discover content in the Research Portal that you believe breaches copyright or violates any law, please contact openaccess@qub.ac.uk. 
Living Independently: Exploring the experiences of visually impaired people living in age-related and Lifetime housing through qualitative synthesis

Authors:

Clıona Rooney, Karim Hadjri, Verity Faith, Mairin Rooney, Keith McAllister \& Cathy Craig. 


\section{ABSTRACT}

The aim of this study is to gain a deeper understanding of the experiences of visually impaired older people living independently at home. As populations are aging globally, there is now an increase in the prevalence of visual impairment. That means for ongoing and future aging-in place strategies that seek to enable older people to remain independent for longer, more attention needs to be given to the needs of those with visual impairment. As people develop visual impairment, they use adaptive strategies including modifying long-term homes or relocating to more suitable accommodation. In the United Kingdom, aging-in-place strategies include employing statutory lifetime home standards (LTHS) in the home or relocating to sheltered housing to live independently with support available if required. To get a better understanding of the needs of the visually impaired in the home, 12 interviews with six visually impaired occupants of LTHS homes and six from sheltered accommodation were analysed separately using interpretative phenomenological analysis. Secondly, qualitative synthesis was used to further analyse themes generated from both samples before interview results were conceptualized in two superordinate concepts, namely, "negotiating priorities" and "understanding visual impairment." Participants from both groups had similar needs and were willing to compromise by living with some negative features. Those who coped well with moving utilized various resources. These findings will shed more understanding on providing good quality housing for those with visual impairment wanting to live either independently or within healthcare home environments.

KEY WORDS Sheltered Housing, Visual Impairment, Lifetime Homes, Ageing in Place, Independent Living 


\section{Introduction}

As global populations age and develop health related impairments, there is a greater incidence of sight loss among older people. This is challenging for designers to address. Older adults with visual impairments, wishing to continue to live independently, often adapt their homes or move to sheltered housing $(\mathrm{SH})$ from less suitable homes. Despite general design guidelines for aiding those with visual impairment, more research is required to analyse the experiences of visually impaired residents in age-related housing. This article therefore presents the experiences of 12visually impaired people living independently in lifetime homes (LTHs) and age-related housing in Northern Ireland (NI).

\section{Background}

Predictions suggest that global percentages of people aged over 60 years will grow from approximately $10 \%$ in 2000 to $13 \%$ by 2020 (United Nations Department of Economic and Social Affairs, 2005). Older people are predisposed to eye conditions such as glaucoma, macular degeneration, and cataract (Stuen \& Faye, 2003). Additionally, the World Health Organization (2012) estimates that $65 \%$ of visually impaired people and $82 \%$ of blind people in the world are aged over 50. Consequently, it is necessary to understand experiences of older adults with impairments to ensure that their housing needs are met. Many visually impaired older people choose to "age-in-place" which is the ability to live independently, safely, and comfortably at home regardless of age, finance, physical, or cognitive limitations (Rowles \& Ravdal, 2004). The United Nations recognizes their right to live independently in the community with equal choices to others (United Nations, 2006). Thus, aging-in place policy aims to develop communities that enable older people to remain in their homes and neighbourhoods for as long as possible (Vasunilashorn, Steinman, Liebig, \& Pynoos, 2012). Much research appraises independent living. Stones and Guilifer (2016) 
use interpretative phenomenological analysis (IPA) to examine experiences of people aged over 85 living at home. Johnson and Bibbo (2014) employ IPA to examine participants' transitions into nursing homes. Studies also explore the experiences of people with glaucoma (Green, Siddall, \& Murdoch, 2002; Wu, Guo, Xia, Lu, \& Xi, 2011). This study specifically considers the housing needs of visually impaired adults living in age-related housing. Housing policy should adapt to afford change as a result of aging and associated impairments (Mackenzie, Curryer, \& Byles, 2015). Lawton's productivity model indicates that homes can be adapted to enhance an individual's competence and meet their changing needs (Wahl, Iwarsson, \& Oswald, 2012). People with impairments use adaptive strategies such as care plans, adjusting their home, or moving to modified housing (Thome'se \& Broese, 2006). Deciding to relocate to SH is often to balance a user's capabilities with the demands of the physical environment (Granbom, Lo“fquist, Horstmann, Haak, \& Iwarsson, 2014).

\subsection{Lifetime Homes}

Lifetime Home Standards (LTHS) seek to reduce the need to relocate or adapt homes when occupants develop impairments. LTHS consist of 16 standards with criteria that pertain to internal and external access alongside fixtures or fittings. LTHS demand inclusive external access with wide car parking and level illuminated access to the home. Internal features include wider doorways, turning spaces, entrance-level living space, provision for bed space at entrance level, entrance-level water closet (WC), provision of bathroom grab rails, space to install a through floor lift, potential for fitting hoists, and an accessible bathroom. Fixtures and fittings standards relate to window height and accessible services controls (Table 1). The benefits of employing LTHS include the adaptability of housing at a minimum cost enabling older people to remain independent for longer (Hanson, 2001; Madigan \& Milner, 1999). 


\section{Table 1: LTHS [Insert table 1 here]}

Despite this, many authors state that LTHS focus solely on physical impairment requirements rather than adequately addressing the needs of visually impaired people (Barlow \& Venables, 2004; Holland \& Peace, 2001; Imrie, 2006; Madigan \& Milner, 1999; Milner \& Madigan, 2004). Nonetheless, LTHS were incorporated into Part $\mathrm{M}^{1}$ of the building regulations ${ }^{2}$ as a higher optional standard (Department for Communities and Local Government, 2015). Hence, LTHS continue to play a major role in the design of UK homes

\subsection{Sheltered Housing}

As older adults with disability spend lengthy periods in their homes, noninstitutional housing connected to services must be developed to enable people to age-in-place (Hamers, Spreeuwenberg, Bilsen, \& Groot, 2008). Housing models such as the Eden Alternative, green house (GH) model, and assisted living were developed as alternatives to traditional nursing home facilities. In line with this, SH are independent homes, usually built near communal facilities and are monitored by wardens (Field, Walker, Hancock, \& Orrell, 2005). SH is often viewed as transitional living between independence in the community and long-term care. Other terms for SH include extra-care and supported housing (Hadjri, 2010). UK studies examining SH identify the importance of designing flexible homes for older people with various care needs (Barnes et al., 2012). While Lewis and Torrington (2012) explore lighting and design of extra-care homes of visually impaired people in England, this article examines the experiences of visually impaired people living in LTHs and SH in NI. This study also questions: Does age-related housing met the needs of visually impaired residents?

\footnotetext{
${ }^{1}$ Part $\mathrm{M}$ of Building Regulations in England are mandatory minimum standards to ensure that people are able to access and use buildings. Building regulations referring to accessibility in Northern Ireland are known as Part R and Part $\mathrm{T}$ in Scotland.

${ }^{2}$ Building regulations are statutory instruments that seek to ensure that the policies set out in the relevant legislation are carried out. Building regulations approval is required for most building work in the UK.
} 


\section{Methodology}

\section{a. Participants \& Interview Procedures}

Purposive homogenous samples of home users were gained through gate keeper housing association (HA) lists and through charity organizations. Two data sets were identified. These were (a) six visually impaired LTHs occupants with a mean age of 59 (L1-L6) and (b) Six visually impaired non-LTHS SH occupants with an average age of over 70 (S1-S6). After ethical approval was granted by Queen's University Belfast, home visits and interviews were carried out with all 12 participants by one member of the research team. Questions were formulated by creating two interview guides, one with questions to be posed and the other with thematic research question (Kvale \& Brinkmann, 2009). The schedule was tested using a pilot interview, and leading questions or jargon was avoided to reduce bias.

Table 2: Participant Descriptions [Insert table 2 here]

\section{b. Data Analysis}

The analysis presented here stems from a larger IPA study that explored the phenomena of visually impaired people living in LTHs. Semi structured in-depth interviews exploring participants' experiences of housing from the two data sets were analysed as two separate groups using IPA, which is a systematic qualitative approach that examined the individual lived experiences of the participants (Osborn \& Smith, 2006). IPA was a suitable method as it allowed for deep descriptions of participants' thoughts and feelings regarding housing challenges they experienced, while acknowledging that researchers may bring certain concepts to the process of analysis

(Reynolds, 2003; Smith, Flowers, \& Larkin,2009). Interviews were analysed individually using the six steps of IPA analysis as devised by Smith et al. (2009)

Table 3: Describing the Six Stages of IPA [Insert table 3 here] 
This involved initial reading, noting, developing emergent themes, searching for connections, moving to the next case, and seeking patterns across cases.

\section{Table 4: Example of Step Three of IPA, Developing Emergent Themes [Insert table 4} here]

Final analysis brought two data sets together (L1-L6 and S1-S6), with the aim of further illuminating the experience of older adults with impairments living independently within community settings. Thus, generated data were further analysed using qualitative synthesis which is a system used o amalgamate a body of research about a particular topic (Hannes \& Lockwood, 2012; Ring, Ritchie, Mandava, \& Jepson, 2010). A variation of meta-ethnography developed by Noblit and Hare (1988) was used to compare, analyse, and further interpret results. Overarching themes were used to identify differences that existed between data sets and to establish an overall picture of living at home with a visual impairment. Noblit and Hare (1988) developed seven steps of meta-ethnography for studies.

\section{Table 5: Seven Steps of Meta-Ethnography [Insert table 5 here]}

The first four steps normally relate to deciding on the relevant studies and organizing them into groups; however, here the two data sets were preselected whereby key concepts had been developed in the form of themes in these studies using IPA. Step 5 was utilized to translate the studies into one another which was carried out by developing concepts from both sample groups. Step 6 then synthesized the translations by identifying concepts that can encompass those found between the two data sets. This was achieved by establishing how the concepts that were developed in Step 5 related to one another. This resulted in developing a map for each group to help describe the relationship between them. Finally, Step 7 involved expressing the synthesis in textual form. 


\section{Results}

Meta-analysis of the results from phenomenological analysis produced two super-ordinate concepts: negotiating priorities and understanding visual impairment. Error! Reference source not found.6 provides a list of super-ordinate and sub-ordinate concepts for discussion.

\section{Table 6: Superordinate Concepts [Insert table 6 here]}

The super-ordinate concept of negotiating priorities was conceptualised in four sub-ordinate concepts: enhancing our homes; housing priorities; compromises and "home sweet home"

\subsection{Negotiating priorities}

\subsubsection{Enhancing our homes}

Both sample groups (L1-L6 and S1-S6) discussed ways of enhancing their homes in the future. Participants (S1-S6) maximized the suitability of their SH by carrying out research when first selecting their residences, while participants in LTHs (L1-L6) considered ways of improving their current homes. Many SH participants had moved home for safety reasons. Safety was also important but not paramount for LTHs participants. Both groups favoured homes with simple layouts and chose homes with level access throughout: "I think that really and truly you couldn't get any better really because everything is on one level" (S6). Many moved to LTHs for further space and wider doorways. One SH participant noted how building and fire regulations had enabled her to feel safer in her home. Others favoured living in familiar house types like their childhood homes. Relationship with others was also an important consideration for allocating homes. Additionally, neighbourhood terrain was important as living on a hill was described as being isolating and dangerous in the winter. Close proximity to amenities and shops was seen as being beneficial by encouraging participants to maintain their independence. Live-in wardens were keys for non-LTH 
sheltered accommodation interviewees: “And I mean let's face it, you say live here alone but it's not really alone, but I have my own life within here" (S6). Although support was valued by both groups, it was still important to prevent an institutional atmosphere in their homes. Participants wanted more consultation between designers and visually impaired people, especially at an early design stage. Participants from both groups used colour contrast on steps and around light switches to aid use. Underfloor heating was also used specifically to lessen the likelihood of trips and falls.

\subsubsection{Housing priorities}

Emotional value was placed on their home in both groups, and participants were attached to their new homes: "It's a home because you make it a home" (S4). Home was described as a base and much time was spent there because it was familiar and satisfied their needs. Both groups felt confidence inside their homes compared to being outside in their neighbourhoods or in the homes of others. All LTHs participants (L1-L6) had moved to a house or apartment that met their accessibility needs. This contrasted with SH participants. For instance, one interviewee had no space to allow two people to stand in her kitchen at the same time. Both groups were satisfied with storage space for equipment, hobbies, and bins in their homes. The extra shower room in LTHs was used by all household members, whereas walk-in showers were not installed initially in the sheltered accommodation. When installed, they were convenient and useful, particularly for older participants and those with physical impairments. Some participants used the shower space as extra storage space. Those living in sheltered accommodation (S1-S6) appreciated the lifts, handrails, and banisters on both sides of stairs and the use of braille in communal areas. LTHs participants (L1-L6) were satisfied with the high-level switches and sockets in their homes although one participant would have liked more switches and sockets. Car ports in LTHS housing not only helped keep people dry 
when approaching their front doors but gave a place for one participant to house her guide $\operatorname{dog}$.

\subsubsection{Compromise}

SH participants (S1-S6) cited negative aspects in their homes alongside LTHs participants (L1-L6) who highlighted challenges that they faced at home and in their neighbourhoods. Although downstairs bathrooms and walk-in showers were important, sometimes shower rooms were too small for wheelchair users alongside their carers. One LTHs participant also wanted an en suite shower room specifically for their bedroom. Many felt safe in their homes: "You lock your door at night and all that and you are safe" (S4), however two LTHs participants felt vulnerable to crime with no direct access to their back gardens. Although there were benefits associated with many LTHS features, one participant commented that LTHS focused principally on physical impairments and complained that features for visual impairment were very expensive to employ. One LTHs participant wanted a more spacious kitchen, whereas another non-LTH SH participant's cupboards were too high and her kitchen door opened inward restricting the amount of usable space. Both groups were dissatisfied with energy efficient light bulbs as they took too long to warm up and thought that natural lighting levels could be improved in internal bathrooms. Two LTHs had condensation issues due to inability to open windows fully for fire safety reasons. Most participants were satisfied with the atmosphere in their homes, however one SH participant described a negative atmosphere in her apartment block which may be a feature of SH with common rooms.

\subsubsection{Home sweet home}

Both groups experienced emotional attachment to their homes and many participants had moved home to live closer to family: 
'Being near them is just lovely, because the doorbell would go and one of my
granddaughters hopped in...um...Friday evening. 'You got the kettle on Gran?' (S6).

At a basic level, homes were fulfilling a purpose, by providing shelter and a base. It was also important for the visually impaired people to tailor their homes to suit their own needs and tastes. Although advised by sensory support teams to alter elements of their homes, sheltered accommodation participants required permission from Housing Associations to make changes: "No, well you can't make changes, they are not our own . . the housing association owns them and they do all and they gave us new kitchens there" (S3). A participant remarked that although advice was important, occupants should have a choice as to whether adjustments are carried out. Both groups described their homes as safe havens where they felt most comfortable and confident.

\subsection{Understanding visual impairment}

The super-ordinate concept of experience of being visually impaired was conceptualised into the sub-ordinate concepts of: adverse reaction; approach to visual impairment; positive frame of mind; relationship with others and needs of visually impaired people.

\subsubsection{Adverse reaction}

Both groups discussed negative reactions toward their visual impairment and experienced adverse reactions, regardless of their home type. Having an ability to read, carry out certain tasks without support, and travel independently outside the home were missed by participants. Cooking independently became challenging. Therefore, participants often relied on family or used microwavable products instead. Those in SH accommodation described their diagnosis as disappointing, while LTHs participants felt a sense of grief and frustration. Both groups lost independence before and after diagnosis. LTHs participants (L1-L6) had 
moved house to gain independence or more space and to receive more support. Similarly, non-LTH SH (S1-S6) participants had moved to homes built to Part R of the Building Regulations to become more independent. Although LTHs are planned with universal design, newly diagnosed physically and visually impaired people selected them for their accessibility features thus helping them to remain independent. Yet, it was important for some to remain in their own familiar home, as vision deteriorated. Non-LTH SH (S1-6) interviewees discussed tripping and falling concerns in the home. Participants cited more space and reduced risk of bumping into obstacles as reasons for moving to LTHS accommodation. It was evident that both samples felt less comfortable and had less control of obstacles outside the home, regardless of standards that their homes were built to: "You see anybody else's house, I am dead lost. I'm terrible, I can't see" (S1). They became more cautious outdoors and often relied on others for support.

\subsubsection{Approach to visual impairment}

This encompassed the use of self-management skills, physical ways of coping, and achieving familiarity with their homes. Although both groups experienced negative reactions following diagnosis, they also learned to accept their visual impairment: "It never seemed to get me down. Do you know? It never got me down. I got on with it" (S6). They coped by focusing on their remaining sight and being mindful of those in more challenging situations. Participants learned to control the effects of impairment. On moving to new homes, they familiarised themselves with surroundings and learned to compensate for lack of sight through mind mapping their home. Both groups stated that moving house could be stressful and challenging, recognising that this process was less challenging for people with partial vision. Both samples used sound and touch to compensate for their loss of vision. Tactile stickers enabled the use of dials on cookers washing machines. Tactile stickers were used 
with digital display to improve the accessibility of heating controls. Both groups removed trip hazards such as rugs.

Physical changes suggested for use in homes included designing with clear layouts, installing nonslip flooring, eliminating door saddles, employing-level access, and avoiding awkward corners or obstructions.

\subsubsection{Positive frame of mind}

All participants discussed the benefits of having a positive emotional response to their sight loss. They also viewed the prospect of deciding to move home positively: "so it was decision time again, and that's never bothered me, if there is a reason for doing something ... I'll get on with it" (S1). Participants went through a process of acceptance and focused on positive thoughts; they were grateful for their homes, their remaining vision, and the support of their families. Those who became visually impaired at a young age stated that they felt that visual impairment was easier to cope in this circumstance. However, some participants felt that they were too accepting of their accommodation: for example, accepting their inability to use the heating control system rather than applying solutions to the problem.

\subsubsection{Relationship with others}

Both groups discussed the level of support that they received from others; non-LTH SH users (S1-S6) discussed societal attitudes, whilst LTHs occupants (L1-L6) commented on the overall support that they received. On examining interview transcripts of both groups, it was evident that support received from family members, HAs, and sensory support teams was appreciated by participants. However, it was also felt important to be aware of when it was appropriate to seek help and to choose carefully how to utilise this assistance while maintaining independence. Members from both groups had care-line systems in their homes 
which could be used to seek help, and although many participants who lived alone found this useful, participants living with others found them obstructive, particularly when children visited their homes. A vital consideration for HAs when allocating homes was that both groups valued their community and wished to live close to family and friends: "sometimes I would go up the stairs after dinner time and some of my neighbours would just sit and have a yarn” (S2). One LTHs participant (L2) had no room for visitors which contributed to negativity and loneliness. This contrasted with another SH participant who appreciated having facilities for guests within her SH complex. Some SH participants felt there was a lack of knowledge regarding their specific needs and were frustrated with poor understanding from members of the public:

"Like...because I am visually impaired I know what to do, but, there are some people who don't. You would see people trying to lead a blind person holding onto them to push them...sort of...through the place. You don't do that". (S2).

\subsubsection{Needs of visually impaired people}

Participants from both groups felt that the housing needs of visually impaired people varied. Many in non-LTHs sheltered accommodation changed aspects of their homes, for instance removing baths and installing showers. Others moved to LTHs to cope with secondary physical conditions. Some older participants spent more time at home, due to a fear of falling outside. The needs of occupants with deteriorating sight were different to those with congenital blindness or with sudden vision loss - for example, the quality and level of lighting necessary in their homes. Some participants from both groups favoured dark spaces and used blinds to control levels of natural light entering a room:

"I don't like the light. I don't put the light on" (L1), others preferred an even spread of light and glare was an issue for many: "If it's dark I can't see. It helps me to see.... it's just easier to see with it" (L5).

Many in both groups wished to improve the levels of natural light entering their bathrooms.

Because the quality of daylight varied from day to day, fluorescent lighting was seen as 
preferable on occasions. However, it could have a negative impact on vision, depending on daily levels of natural light and so was not universally popular.

\section{Discussion}

This article has sought to provide a deeper understanding of the experiences of visually impaired people who live in age-related housing in a UK context by interviewing residents with visual impairment living in both LTHs and SH. Although most participants were satisfied with their homes, they were also willing to tolerate some negative features. It is clear that residents set their housing priorities and compromised between practicalities and their wishes within their homes. Both groups had similar housing expectations and highlighted the importance of feeling safe at home. This was achieved through design measures and changing their habits, with both groups expressing similar values with particular regard to inclusion within communities. This aligns with Wiles, Leibing, Guberman, Reeve, and Allen (2011) who observe that older people aging-in-place are most settled in safe communities enabling a feeling of security in their homes. However, there were also negative aspects with independent community living, whereby participants could be targeted by crime or where other people had lacked understanding toward them.

As with previous research, colour contrasting features, extra storage space, and spare visitor rooms are important to participants (Johnson \& Bibbo, 2014; Lenham, 2013; Sylvestre \& Smith, 2009). Both groups found that design features developed for older people benefit them and stated that many impairment types are considered in the design of their homes. However, those who lived in homes with low social density had a greater need for technology such as care line systems, yet those with high social density dwellings found more obtrusive. Colour contrast is useful for those with partial visual loss (Foxlin, 2014), yet further consultation at an early design stage could be improved to enhance future homes. 
In line with the social model of disability, residents were disabled by society, when their needs were not understood by members of the public and through an absence of key facilities (Bolt, 2005). Occupants noted a lack of control over decisions regarding internal changes to their homes. Preceding research identifies mobility or health decline reasons for older people moving home (Ermisch \& Jenkins, 1999; Granbom et al., 2014; Seo \& Mazumdar, 2011; Sylvestre \& Smith, 2009). Here, all LTHS participants (L1-L6) moved to find more physically accessible accommodation, indicating a need for further accessibility in general housing stock. The SH examined was built to Part $\mathrm{R}$ of building regulations which is a visitability10 access standard covering accessibility. Evidently, Part R and LTHS criteria are beneficial to both groups of participants, in particular with regard to level access design. However, building regulations and LTHS excluded features that participants favour including underfloor heating, colour contrast, access to views from homes, location of homes, support available, and considering the emotional attachment to their homes. These could be considered by HAs and others when designing and allocating housing for visually impaired people. The design of care homes for visually impaired people can also benefit from these findings given the domestic features that these should afford.

The LTHS group complimented accessibility features such as carports, height of switches/sockets, extra space, additional shower room, walk-in shower, and wider doorways, whilst members of the SH group favoured lifts and banisters in communal areas. Conversely, both groups cited negative features such as poor heating controls in awkward locations, small kitchen spaces, and poor lighting levels. Educating older people and housing providers to determine adequate levels of appropriate light for age-related visually impaired people is critical (Eilertsen, Horgen, Kvikstad, \& Falkenberg, 2016). In both groups, a sense of community was important, and homes were enhanced by support and presence of others, affirming Rowle and Ravdal's (2004) theory that social emersion enables development of 
affinity toward home or place. Accepting support of others to improve coping skills correlates with Antonovsky's (1979) salutogenic theory of sense coherence that describes general resistance resources such as social support, coping strategies, and cultural stability inherent in people with strong abilities to deal with challenges (Eriksson \& Lindstrom, 2005). A sense of coherence (SOC) is a capability to perceive that one can cope irrespective of challenges that they face (Lindstrom \& Eriksson, 2006).

In order for the built environment to have positive effects on SOC for occupants, buildings must be easily understood, afford control, and have meaning (Golembiewski, 2010). Unsuitable non-LTHS features were inaccessible cupboards and awkward kitchen spaces. Poor features for LTHS occupants included heavy doors, lack of bathroom space for carers, and awkward window openings. Also negative features unrelated to design in both settings were poor atmospheres and trip hazards. Non-adapted use of space was also, evident when occupants relied on family members to cook meals. Brundle et al. (2015) identify clutter as a risk for falls in familiar home environments. Although gossip contributed to negative moods in study findings here, Percival (2000) suggests that it has necessary social purposes in sheltered homes. In line with this, Hadjri, Rooney, and Faith (2015) state that a good atmosphere is also an important element within care homes for people with dementia. Overall, both groups had similarities in what home means to them, had pride in their houses, realising that home provided them with shelter alongside a sense of community. Wiles (2008) notes that familiarity plays an important role in developing a sense of home. In line with this, living in familiar settings or house types was important to participants. This correlates with (Rowles \& Ravdal, 2004; Swenson, 1998) findings where home acts as a base or shelter and a symbol of oneself. It is also in keeping with the principles of GH and assisted living principles, which suggest that residents should be able to age-in-place in a homelike environment designed to cater for their changing needs (Spitzer \& Neuman, 2004). 
Furthermore, GH homes are built to blend with surrounding houses and neighbourhoods. Research states that people may react to diagnoses of visual impairment with shock and fear for the future (Green et al., 2002; Wu et al., 2011).

In the present study, participants faced new challenges both inside and outside the home. Both groups discussed negative consequences of visual impairment and voiced a sense of loss, lack of control, and a sense of grief or frustration. Evidently all faced these challenges in a positive way and learned new ways to carry out tasks focusing on positive thoughts. Research into care home design shows that moving home can be uncertain and frustrating (Rowles \& Ravdal, 2004). LTHS participants (L1-L6) who moved to more accessible homes then used touch and sound to become familiar with new spaces. Although adjustments to the home can counterbalance the negative effects that impairment can have on wellbeing, existing housing stock is not always adaptable and sometimes there is a need to move (Thome'se \& Broese, 2006). This corroborates previous findings that new memories, emotional attachments, and meanings can be built by deciding to move autonomously (Leith, 2006). This complies with Nahemow and Lawton's (1973) ecological theory where the demands of the environment became too challenging. However, by moving to LTHS homes, participants are enabling themselves to age-in-place. On comparing the results of interviews, it is evident that both groups have similar experiences of housing and visual impairment.

\section{[Insert figure 1]}

\section{Conclusion}

This article provides an in-depth analysis of perceptions of visually impaired people in a range of homes. Our findings suggest that oftentimes people leave general housing and move to more accessible homes. As LTHs should reduce the need to move in future, it means that more thought and attention needs to be given to providing good quality aging-in-place 
housing for those with a wide range of disabilities, including visual impairment. The loss of capacity and increased likelihood of depression associated with any disability only increases the need to ensure that residents with a visual impairment do feel genuinely comfortable and at ease in their homes and wider surroundings. These findings are therefore also applicable to the design of healthcare facilities. Hence further research is now needed to evaluate the quality of our existing housing stock and how both it and new housing can provide a safe and secure home for many who face difficult physical challenges in their lives (Figure 1 and Table 7).

\section{Implications for Practice}

i. There will be a need to upgrade mainstream housing stock to afford more choice and to enable people to age-in-place.

ii. There is a need to educate residents and housing providers to determine adequate levels of appropriate lighting for age-related visual impairment.

iii. Further research is needed to examine the inclusion of features such as underfloor heating and colour contrast in current building regulations (Part $\mathrm{R}$ and lifetime home standards).

iv. Any loss in physical capacity can have a negative effect on a person's well-being, therefore feeling both comfortable and confident in one's surroundings is important to counterbalance this.

v. Findings such as the need for access to views, improving heating controls, lighting levels, and creating buildings with meaning are also applicable to the design of care home environments. 


\section{Acknowledgments}

The research team would like to thank the individuals and organisations who generously shared their time, experience, and materials for the purposes of this research.

\section{References}

Antonovsky, A. (1979). Health, Stress and Coping. San Francisco, CA: Jossey-Bass Publishers.

Barlow, J., \& Venables, T. (2004). Will technological innovation create the true lifetime home? Housing Studies, 19(5), 795-810.

Barnes, S., Torrington, J., Darton, R., Holder, J., Lewis, A., McKee, K., Netten, A., \& Orrell, A. (2012). Does the design of extra-care housing meet the needs of the residents? A focus group study. Ageing and Society, 32(7), 1193-1214.

Bodner, E., Cohen-Fridel, S., \& Yaretzky, A. (2011). Sheltered housing or community dwelling: Quality of life and ageism among elderly people. International Psychogeriatrics, 23(8), 1197-1204.

Bolt, D. (2005). From blindness to visual impairment: terminological typology and the social model of disability. Disability \& Society, 20, 539-552.

Bouldin, E. D., Andresen, E. M., Bauer, S. E., Whitney, C., Tamayo, C. C., Schumacher, J. R., \& Hall, A. G. (2015). Visitability surveillance, prevalence, and correlates in Florida. Disability and Health Journal, 8(1), 140-145.

Brundle, C., Waterman, H. A., Ballinger, C., Olleveant, N., Skelton, D. A., Stanford, P., \& Todd, C. (2015). The causes of falls: Views of older people with visual impairment. Health Expectations, 18(6), 2021-2031.

Department for Communities and Local Government. (2015). Housing standards review. Final implementation impact assessment. London: Department for Communities and Local Government.

Eilertsen, G., Horgen, G., Kvikstad, T. M., \& Falkenberg, H. K. (2016). Happy living in darkness! indoor lighting in relation to activities of daily living, visual and general health in 75-year-olds living at home. Journal of Housing for the Elderly, 30(2), 199-213.

Eriksson, M., \& Lindstrom, B. (2005). Validity of Antonovsky's sense of coherence scale: a systematic review. Journal of Epidemiology and Community Health, 59(6), 460-466.

Ermisch, J. F., \& Jenkins, S. P. (1999). Retirement and housing adjustment in later life: Evidence from the british household panel survey. Labour Economics, 6(2), 311-333. 
Field, E., Walker, M., Hancock, G., \& Orrell, M. (2005). The needs of older people in sheltered housing: A comparison of inner city and new town areas. Journal of Housing for the Elderly, 19(2), 107-117.

Foxlin, S. C. (2014). Designing for people with visual impairments. Journal of Visual Impairment \& Blindness, 108(4), 342- 346.

Golembiewski, J. A. (2010). Start making sense: Applying a salutogenic model to architectural design for psychiatric care. Facilities, 28(3-4), 100-117.

Granbom, M., Löfqvist, C., Horstmann, V., Haak, M., \& Iwarsson, S. (2014). Relocation to ordinary or special housing in very old age: Aspects of housing and health. European Journal of Ageing, 11(1), 55-65.

Green, J., Siddall, H., \& Murdoch, I. (2002). Learning to live with glaucoma: A qualitative study of diagnosis and the impact of sight loss. Social Science \& Medicine, 55(2), 257-267.

Hadjri, K. (2010). An assessment of sheltered housing design in Belfast, Northern Ireland. Journal of Housing for the Elderly, 24(2), 171-192.

Hadjri, K., Rooney, C., \& Faith, V. (2015). Housing choices and care home design for people with dementia. HERD, 8, 80-95.

Hamers, J. P. H., Spreeuwenberg, C., Bilsen, V. P.M.A., \& Groot, W. (2008). Sheltered housing compared to independent housing in the community. Scandinavian Journal of Caring Sciences, 22(2), 265-274.

Hannes, K., \& Lockwood, C. (2012). Synthesising qualitative research :Choosing the right approach. Chichester: Wiley-Blackwell.

Hanson, J. (2001). From sheltered housing to lifetime homes: An inclusive approach to housing. In S. Winters (Ed.), Lifetime housing in europe (pp. 35-57). Leuven: Katholieke Unversiteit Leuven.

Holland, C., \& Peace, S. (2001). Housing in an ageing society, innovative approaches . In S. Peace, \& C. Holland (Eds.), Inclusive housing (pp. 235-261). Bristol: The Policy Press.

Imrie, R. (2006). Independent lives and the relevance of lifetime homes. Disability \& Society, 4, 359-374.

Johnson, R., \& Bibbo, J. (2014). Relocation decisions and constructing the meaning of home: A phenomenological study of the transition into a nursing home. Journal of Aging Studies, 30(1), 56-63.

Kvale, S., \& Brinkmann, S. (2009). Interviews learning the craft of qualitative research interviewing ( $2^{\text {nd }}$ ed.). London, England: Sage.

Leith, K. H. (2006). "Home is where the heart is...or is it?". A phenomenological exploration of the meaning of home for older women in congregate housing. Journal of Aging Studies, 20, 317-333. 
Lenham, J. (2013). Colour, contrast and comfort: Interior design in dementia. Nursing \& Residential Care, 15(9), 616-618.

Lewis, A., \& Torrington, J. (2012). Extra-care housing for people with sight loss: Lighting \& design. Lighting Research and Technology, 45(3), 1-17.

Lindstrom, B., \& Eriksson, M. (2006). Contextualizing salutogenesis and antonovsky in public health development. Health Promotion International, 21(3), 238-244.

Mackenzie, L., Curryer, C., \& Byles, J. E. (2015). Narratives of home and place: Findings from the housing and independent living study. Ageing \& Society, 35(8), 1684-1712

Madigan, R., \& Milner, J. (1999). Access for all: Housing design and the disability discrimination act 1995. Critical Social Policy, 19(3), 396-409.

Milner, J., \& Madigan, R. (2004). Regulation and innovation: Rethinking 'Inclusive' housing design. Housing Studies, 19(5), 727-744.

Nahemow, L., \& Lawton, M. P. (1973). Toward an ecological theory of adaptation and aging. Environmental Design Research, 1, 24-32.

Noblit, G. W., \& Hare, R. D. (1988). Meta-ethnography: Synthesizing qualitative studies. London: Sage Publications.

Osborn, M., \& Smith, J. A. (2006). Living with a body separate from the self. the experience of the body in chronic benign low back pain: An interpretative phenomenological analysis. Scandinavian Journal of Caring Science, 20, 216-222.

Percival, J. (2000). Gossip in sheltered housing: Its cultural importance and social implications. Ageing and Society, 20(3), 303-325.

Preiser, W. F. E., \& Ostroff, E. (2001). Universal design handbook. New York, NY: McGraw-Hill.

Reynolds, F. (2003). Exploring the meaning of artistic occupation for women living with chronic illness: A comparision of template and interpretative phenomenological approaches to analysis. British Journal of Occupational Therapy, 66(12), 551-558.

Ring, N., Ritchie, K., Mandava, L., \& Jepson, R. (2010). A guide to synthesising qualitative research for researchers undertaking health technology assessments and systematic reviews. Scotland: NHS quality improvement Scotland.

Rowles, G., \& Ravdal, H. (2004). Aging, place and meaning in the face of changing circumstances. In R. S. Weiss, \& S. A. Bass (Eds.), Challenges of the third age: Meaning and purpose in later life (New ed., pp. 81-114). New York; Oxford [England]: Oxford University Press.

Seo, Y. K., \& Mazumdar, S. (2011). Feeling at home: Korean americans in senior public housing. Journal of Aging Studies, 25(3), 233-242. 
Smith, J. A., Flowers, P., \& Larkin, M. (2009). Interpretative phenomenological analysis theory, method and research. London: Sage.

Spitzer, W. J., \& Neuman, K. (2004). The coming of age for assisted living care. Social Work in Health Care, 38, 21-45.

Stones, D., \& Gullifer, J. (2016). 'At home it's just so much easier to be yourself': Older adults' perceptions of ageing in place. Ageing \& Society, 36(3), 449-481.

Stuen, C., \& Faye, E. (2003). Vision loss: Normal and not normal changes among older adults. Generations: The Journal of the American Society on Ageing, 27, 8-14.

Swenson, M. (1998). The meaning of home to five elderly women. Health Care for Women International, 19(5), 381-393.

Sylvestre, G. M., \& Smith, G. C. (2009). Spatial aspects of the residential adjustments of older parents moving to low-income senior housing: A longitudinal study. Geoforum, 40(5), 918-929.

Thomése, F., \& Broese, V. G. (2006). Adaptive strategies after health decline in later life: Increasing the person-environment fit by adjusting the social and physical environment. European Journal of Ageing, 3(4), 169-177.

United Nations. (2006). Convention on the rights of persons with disabilities. Retrieved from http://www.un.org/disabilities/convention/convention.shtml

United Nations Department of Economic and Social Affairs. (2005). Living arrangements of older persons around the world. New York: United Nations.

Vasunilashorn, S., Steinman, B., Liebig, P., \& Pynoos, J. (2012). Aging in place: Evolution of a research topic whose time has come. Journal of Aging Research. 1-6.

Wahl, H., Iwarsson, S., \& Oswald, F. (2012). Aging well and the environment: Toward an integrative model and research agenda for the future. Gerontologist, 52(3), 306-316.

Wiles, J. (2008). Sense of home in a transnational social space: New Zealanders in London. Global Networks, 8, 116-137.

Wiles, J. L., Leibing, A., Guberman, N., Reeve, J., \& Allen, R. (2011). The meaning of 'ageing in place' to older people. The Gerontologist, 52(3), 357-366.

World Health Organisation. (2012). Global data on visual impairments 2010. Switzerland: World Health Organisation.

Wu, P. X., Guo, W. Y., Xia, H. O., Lu, H. J., \& Xi, S. X. (2011). Patients' experience of living with glaucoma: A phenomenological study. Journal of Advanced Nursing, 67(4), 800810. 
Tables

Table 1: Lifetime Home Standards

\begin{tabular}{|c|c|}
\hline Criteria & Description \\
\hline 1. Parking & Wider parking bays \\
\hline 2. Approach to dwelling & $\begin{array}{l}\text { Ease of approach from parking area to } \\
\text { dwelling }\end{array}$ \\
\hline 3. Approach to all entrances & $\begin{array}{l}\text { The approach to all entrance areas should be } \\
\text { level or gently sloping }\end{array}$ \\
\hline 4. Entrances & $\begin{array}{l}\text { All entrances should be illuminated and } \\
\text { have level access }\end{array}$ \\
\hline 5. Communal stairs and lifts & Main stairs should provide easy access \\
\hline 6. Internal doorways and hallways & Wider doorways and hallways \\
\hline 7. Circulation space & Circulation space for turning wheelchairs \\
\hline 8. Entrance level living space & Living room provided at entrance level \\
\hline $\begin{array}{l}\text { 9. Potential for entrance level bed } \\
\text { space }\end{array}$ & Space for temporary bed-space \\
\hline $\begin{array}{l}\text { 10. Entrance level WC and shower } \\
\text { drainage }\end{array}$ & $\begin{array}{l}\text { Access to WC and shower at entrance-level } \\
\text { drainage }\end{array}$ \\
\hline 11. WC and bathroom walls & Walls should be capable of firm fixing \\
\hline $\begin{array}{l}\text { 12. Stairs and potential through floor lift } \\
\text { in dwelling }\end{array}$ & $\begin{array}{l}\text { Two story homes should have a suitable } \\
\text { space identified for through } \\
\text { floor lift }\end{array}$ \\
\hline $\begin{array}{l}\text { 13. Potential for fitting of hoists and } \\
\text { bedroom/bathroom }\end{array}$ & $\begin{array}{l}\text { Structure in main bedroom should be } \\
\text { capable of supporting a hoist }\end{array}$ \\
\hline 14. Bathrooms & Provide an accessible bathroom \\
\hline 15. Glazing and window handle heights & $\begin{array}{l}\text { Living space windows should allow people } \\
\text { to see out when seated }\end{array}$ \\
\hline 16. Location of service controls & Fixings should be at an accessible height \\
\hline
\end{tabular}


Table 2: Participant Descriptors

\begin{tabular}{|l|l|l|l|l|l|l|}
\hline \multicolumn{3}{|l|}{ Sheltered Housing Participants } \\
No. & Age & $\begin{array}{l}\text { Type of } \\
\text { Impairment }\end{array}$ & Level & $\begin{array}{l}\text { Other } \\
\text { Conditions }\end{array}$ & $\begin{array}{l}\text { Tears Since } \\
\text { Registration }\end{array}$ & $\begin{array}{l}\text { Living } \\
\text { Alone or } \\
\text { With } \\
\text { Another }\end{array}$ \\
\hline 1 & 83 & $\begin{array}{l}\text { Age-related } \\
\text { macular } \\
\text { degeneration }\end{array}$ & Blind & Heart condition & 5 & Alone \\
\hline 2 & 77 & $\begin{array}{l}\text { Congenital } \\
\text { cataracts and lost } \\
\text { sight in one }\end{array}$ & $\begin{array}{l}\text { Partially } \\
\text { sighted }\end{array}$ & $\begin{array}{l}\text { Diabetes heart } \\
\text { condition }\end{array}$ & 77 & Alone \\
\hline 3 & 93 & $\begin{array}{l}\text { Macular } \\
\text { degeneration and } \\
\text { cataracts }\end{array}$ & $\begin{array}{l}\text { Partially } \\
\text { sighted }\end{array}$ & $\begin{array}{l}\text { Heart condition } \\
\text { and arthritis }\end{array}$ & 23 & Alone \\
\hline 4 & 81 & $\begin{array}{l}\text { Tunnel vision } \\
\text { blind in one eye }\end{array}$ & Blind & $\begin{array}{l}\text { Sciatica and } \\
\text { stroke }\end{array}$ & 12 & Alone \\
\hline 5 & 83 & $\begin{array}{l}\text { Blind in one eye } \\
\text { 25\% vision in } \\
\text { other }\end{array}$ & Blind & $\begin{array}{l}\text { Brain } \\
\text { hemorrhage and } \\
\text { arthritis }\end{array}$ & 10 & Alone \\
\hline 6 & 79 & $\begin{array}{l}\text { Retinitis } \\
\text { pigmentosa }\end{array}$ & Blind & $\begin{array}{l}\text { Minor deafness } \\
\text { and arthritis }\end{array}$ & 56 & Alone \\
\hline
\end{tabular}

\begin{tabular}{|c|c|c|c|c|c|c|}
\hline \multicolumn{7}{|c|}{ Lifetime Home Participants } \\
\hline $\begin{array}{l}\text { L } \\
\text { No. }\end{array}$ & Age & $\begin{array}{l}\text { Type of } \\
\text { Impairment }\end{array}$ & Level & $\begin{array}{l}\text { Other } \\
\text { Conditions }\end{array}$ & $\begin{array}{l}\text { Tears Since } \\
\text { Registration }\end{array}$ & $\begin{array}{l}\text { Living } \\
\text { Alone or } \\
\text { With } \\
\text { Another }\end{array}$ \\
\hline 1 & 82 & Glaucoma & Blind & Arthritis & 12 & Alone \\
\hline 2 & 45 & $\begin{array}{l}\text { Retinal } \\
\text { detachment }\end{array}$ & $\begin{array}{l}\text { Partially } \\
\text { sighted }\end{array}$ & Diabetes & 7 & Alone \\
\hline 3 & 43 & $\begin{array}{l}\text { Congenital } \\
\text { glaucoma and } \\
\text { corneal damage }\end{array}$ & $\begin{array}{l}\text { Partially } \\
\text { sighted }\end{array}$ & Diabetes & 43 & $\begin{array}{l}\text { With } \\
\text { Others }\end{array}$ \\
\hline 4 & 47 & Diplopia & Blind & $\begin{array}{l}\text { Poor hearing \& } \\
\text { asphyxia due to } \\
\text { acoustic } \\
\text { neuroma }\end{array}$ & 10 & $\begin{array}{l}\text { With } \\
\text { Others }\end{array}$ \\
\hline 5 & 83 & $\begin{array}{l}\text { Age-related } \\
\text { macular } \\
\text { degeneration and } \\
\text { one eye removed } \\
\text { due to tumor }\end{array}$ & Blind & None & 33 & Alone \\
\hline 6 & 51 & $\begin{array}{l}\text { Blind in left eye } \\
\text { and peripheral } \\
\text { vision only in } \\
\text { right eye }\end{array}$ & Blind & Aphasia & 4.5 & $\begin{array}{l}\text { With } \\
\text { Others }\end{array}$ \\
\hline
\end{tabular}


Table 3: Describing the Six Steps of IPA (Smith, Flowers, \& Larkin, 2009).

\begin{tabular}{|l|l|}
\hline Steps & Process \\
\hline 1. Reading and rereading & Read transcript multiple times \\
\hline 2. Initial noting & $\begin{array}{l}\text { Made descriptive, linguistic, and conceptual } \\
\text { comments for each transcript }\end{array}$ \\
\hline 3. Developing emergent themes & $\begin{array}{l}\text { Analysed comments to create emergent } \\
\text { themes }\end{array}$ \\
\hline $\begin{array}{l}\text { 4. Searching for connections across } \\
\text { emergent themes }\end{array}$ & $\begin{array}{l}\text { Developed superordinate themes by } \\
\text { analysing emergent themes }\end{array}$ \\
\hline 5. Moving to the next case & $\begin{array}{l}\text { Analysed the next transcript in the using the } \\
\text { same technique }\end{array}$ \\
\hline 6. Looking for patterns across cases & $\begin{array}{l}\text { Created a master table of themes using } \\
\text { superordinate themes from each case }\end{array}$ \\
\hline
\end{tabular}

Table 4: Example of Step Three of Interpretative Phenomenological Analysis, Developing Emergent Themes (Smith, Flowers, \& Larkin, 2009).

\begin{tabular}{|c|c|c|}
\hline Emergent Theme & Original Transcript & Exploratory Comments \\
\hline $\begin{array}{l}\text { Small space } \\
\text { Inclusive environment } \\
\text { Satisfaction } \\
\text { Long-term support }\end{array}$ & $\begin{array}{l}\text { Um. . . well it's a one } \\
\text { bedroom flat . . . built } \\
\text { as sheltered accommodation } \\
\text { which includes elderly ... } \\
\text { disabled all kinds of } \\
\text { disablement, } \\
\text { and so on. } \\
\text { Um. . . which is a } \\
\text { tremendous idea ... this one } \\
\text { has a permanent live in } \\
\text { um. . . manager }\end{array}$ & $\begin{array}{l}\text { Built for a specific group } \\
\text { Tremendous: positive } \\
\text { language }\end{array}$ \\
\hline
\end{tabular}


Table 5: Seven Steps of Meta-Ethnography (Noblit \& Hare, 1988).

\begin{tabular}{|c|c|}
\hline Steps & Description \\
\hline Getting started & Beginning the research \\
\hline Deciding what is relevant to the initial interest & Deciding on the scope of the study \\
\hline Reading the studies & $\begin{array}{l}\text { Reading chosen papers to form key } \\
\text { concepts }\end{array}$ \\
\hline Determining how the studies are related & $\begin{array}{l}\text { Searching for common concepts between } \\
\text { papers }\end{array}$ \\
\hline Translating the studies into one another & Creating a grid to compare papers \\
\hline Synthesising translations & $\begin{array}{l}\text { Establishing relationships between } \\
\text { concepts }\end{array}$ \\
\hline Expressing the synthesis & Reporting the synthesis \\
\hline
\end{tabular}

Table 6: Superordinate Concepts

\begin{tabular}{|l|l|}
\hline Superordinate Concepts & Subordinate Concepts \\
\hline Negotiating priorities & Enhancing our homes \\
\cline { 2 - 2 } & Housing priorities \\
\cline { 2 - 2 } & Compromises \\
\cline { 2 - 2 } & Home sweet home \\
\hline Understanding visual impairment & Adverse reaction \\
\cline { 2 - 2 } & Approach to visual impairment \\
\cline { 2 - 2 } & Positive frame of mind \\
\cline { 2 - 2 } & Relationship with others \\
\cline { 2 - 2 } & Needs of visually impaired people \\
\hline
\end{tabular}


Table 7: Evidence-Based Recommendations.

\begin{tabular}{|c|c|c|}
\hline $\begin{array}{l}\text { Superordinate } \\
\text { Concepts }\end{array}$ & $\begin{array}{l}\text { Subordinate } \\
\text { Concepts }\end{array}$ & Recommendations \\
\hline \multirow[t]{9}{*}{$\begin{array}{l}\text { Negotiating } \\
\text { priorities }\end{array}$} & \multirow[t]{3}{*}{$\begin{array}{l}\text { Enhancing our } \\
\text { homes }\end{array}$} & $\begin{array}{l}\text { More consultation between visually impaired people } \\
\text { and designers, especially at early design stage }\end{array}$ \\
\hline & & Greater use of colour contrast \\
\hline & & Install underfloor heating \\
\hline & \multirow[t]{3}{*}{ Housing priorities } & Afford extra space in kitchens \\
\hline & & Allow extra storage space for equipment \\
\hline & & $\begin{array}{l}\text { Add accessible showers to existing } \mathrm{SH} \text { where } \\
\text { possible }\end{array}$ \\
\hline & Compromises & Improve lighting levels in bathrooms \\
\hline & \multirow[t]{2}{*}{ Home sweet home } & $\begin{array}{l}\text { Allocate familiar house types or homes in local area } \\
\text { to HA residents }\end{array}$ \\
\hline & & $\begin{array}{l}\text { Afford more control for visually impaired residents } \\
\text { to alter sheltered homes }\end{array}$ \\
\hline \multirow{8}{*}{$\begin{array}{l}\text { Understanding } \\
\text { visual } \\
\text { impairment }\end{array}$} & Adverse reaction & $\begin{array}{l}\text { Improve existing housing stock to reduce the need to } \\
\text { move home }\end{array}$ \\
\hline & \multirow[t]{2}{*}{$\begin{array}{l}\text { Approach to visual } \\
\text { impairment }\end{array}$} & $\begin{array}{l}\text { Provide contact details for sensory support teams to } \\
\text { visually impaired people moving home for access } \\
\text { reasons }\end{array}$ \\
\hline & & Design clear layouts that eliminate clutter \\
\hline & \multirow[t]{2}{*}{$\begin{array}{l}\text { Positive frame of } \\
\text { mind }\end{array}$} & $\begin{array}{l}\text { Provide information about how to use heating } \\
\text { systems }\end{array}$ \\
\hline & & Ensure that heating controls are accessible \\
\hline & \multirow[t]{2}{*}{$\begin{array}{l}\text { Relationship with } \\
\text { others }\end{array}$} & $\begin{array}{l}\text { Tailor the installation of electronic devices to suit } \\
\text { individuals }\end{array}$ \\
\hline & & Provide guest room facilities \\
\hline & $\begin{array}{l}\text { Needs of visually } \\
\text { impaired people }\end{array}$ & $\begin{array}{l}\text { Input from sensory support teams is important to } \\
\text { determine individual needs }\end{array}$ \\
\hline
\end{tabular}




\section{Figure 1: Implications For Practice}

\section{What is already known about this topic}

- The number of visually impaired people is increasing.

- As people grow older or develop impairments, they use adaptive strategies including modifying long-term homes or relocating to more accessible housing.

- Lifetime homes aim to reduce the need to modify existing homes and move home.

- Previous research has not focused on the housing needs of visually impaired people living independently in a range of homes.

\section{What this paper adds}

- A deeper understanding of experiences of visually impaired people who live in Lifetime homes and sheltered housing.

- Older people are willing to compromise and live with negative housing features.

- Design features that cater for the general aging population are of benefit to visually impaired older people.

- Older visually impaired people who cope well with moving have many general resistance resources (GRR).

\section{Implications for practice and/or policy}

- There may be a need to upgrade general housing stock to afford more choice and to enable people to age-in-place.

- Future architectural research would benefit by using Qualitative Synthesis and IPA.

- Further research is needed to establish and improve the quality of existing housing stock. 